\title{
SYNTHESIS AND INVESTIGATION OF ANTHELMINTIC, ANTIBACTERIAL AND ANTIFUNGAL ACTIVITY OF 3,3-DIPHENYL PROPANAMIDE DERIVATIVES
}

\author{
SACHIN CHAUDHARY ${ }^{1 *}$, HARISH CHANDRA VERMA ${ }^{2}$, MANDEEP KUMAR GUPTA ${ }^{2}$, RAMESH KUMAR GUPTA ${ }^{2}$, \\ AMIT KUMAR ${ }^{3}$, ABDEL NASSER EL-SHORBAGI ${ }^{1,4}$
}

${ }^{1}$ Department of Medicinal Chemistry, College of Pharmacy, University of Sharjah, Sharjah, United Arab Emirates. ${ }^{2}$ Moradabd Education Trust Group of Institutions Faculty of Pharmacy, Moradabad, Uttar Pradesh, India. ${ }^{3}$ Neelkanth Group of Institutions, College of Pharmacy, Meerut, Uttar Pradesh, India. ${ }^{4}$ Sharjah Institute for Medical Research, University of Sharjah, Sharjah, United Arab Emirates. Email: schaudhary@sharjah.ac.ae

Received: 03 October 2018, Revised and Accepted: 12 November 2018

ABSTRACT

Objective: A novel series of substituted 3,3-diphenyl propanamide derivatives (I-VIII) were synthesized by reacting 3,3-diphenyl propanoyl chloride with different amines/amino acids, and all the derivatives were investigated for anthelmintic, antibacterial, and antifungal activity.

Methods: All the compounds were characterized by infrared (IR) and ${ }^{1} \mathrm{H}$ - nuclear magnetic resonance spectrometry data. The synthesized derivatives were investigated for their anthelmintic activity employing housefly worms method and earthworm species model. The antibacterial and antifungal activity was performed employing cup plate method.

Results: The synthesized compounds (VII and VIII) exhibited maximum anthelmintic activity as compared with standard drug albendazole at doses of 50 and $100 \mathrm{mg} / \mathrm{mL}$, due to minimal paralyzing and death time in both housefly and earthworm models. The compounds (IV, VII, and VIII) at $50 \mu \mathrm{g} / \mathrm{mL}$ exhibited maximum activity against Gram-negative bacterial strains, namely, Escherichia coli, Pseudomonas aeruginosa as compared with ciprofloxacin and same compounds exhibited maximum antifungal activity against Candida albicans and Aspergillus niger in comparison with standard drug griseofulvin at $50 \mu \mathrm{g} / \mathrm{mL}$.

Conclusion: The synthesized compounds bearing amino acid moiety in their structure (VII-VIII) exhibited impressive anthelmintic activity in comparison with albendazole. This suggests that amino acid/peptide derivative of diphenyl propanamides can act as great anthelmintic agents. Further, the research can be performed to design potent antimicrobial diphenyl propanamide derivatives.

Keywords: 3,3-Diphenyl propanamide, Antibacterial, Antifungal, Anthelmintic.

(c) 2019 The Authors. Published by Innovare Academic Sciences Pvt Ltd. This is an open access article under the CC BY license (http://creativecommons. org/licenses/by/4. 0/) DOI: http://dx.doi.org/10.22159/ajpcr.2019.v12i1.30094

\section{INTRODUCTION}

Inadequate novel antimicrobial agents and elevating bacterial resistance toward antimicrobials are a predominant topic in the field of drug development and studies [1,2]. Microbial infections have proliferated unexpectedly in the past 20 years due to antimicrobial resistance, intensification in impaired immune system patients due to HIV, cancer chemotherapy, and organ transplantation worldwide [3,4]. Despite noteworthy approach in the field of antimicrobial therapy, the increase in consumption and misuse of antibiotics have caused the emergence of bacterial resistance toward antibiotics $[5,6]$. In the present scenario, health problems demand to synthesize and investigate a novel class of antimicrobial agent proved to be active against microbes that are resistant toward currently used antibiotics [7]. TheJrefore, considering the pharmacological potential of aryl propioninc acid derivatives [8-12], novel derivatives of substituted 3,3-diphenyl propanamide were synthesized and investigated for their antibacterial, antifungal, and anthelmintic activity against housefly worms and earthworm species.

\section{Experimental}

Chemistry

General

Melting points were determined by the open capillary method and were uncorrected. IR spectra were recorded on a Shimadzu 8700 Fourier-transform infrared spectrophotometer (Shimadzu, Japan) using $\mathrm{KBr}$ pellets. Nuclear magnetic resonance $\left({ }^{1} \mathrm{H}-\mathrm{NMR}\right)$ was recorded on a Bruker AC NMR spectrometer (300 MHz), (Bruker, USA) using
$\mathrm{CDCl}_{3}$ as a solvent. Purity of all compounds was checked by thin-layer chromatography on pre-coated silica gel G plates (Kieselgel $0.25 \mathrm{~mm}$, 60G F254, Merck, Germany) using petroleum ether/ethyl acetate as developing solvent system in proportion $(4: 1)$ for compounds (I-V) and petroleum ether/ethyl acetate/ethanol in proportion (4:5:1) for compounds (VI-VIII). All the chemicals and solvents were purchased from Research Lab Fine Chem Industries, Mumbai, India.

\section{Synthesis of 3,3-diphenyl propionic acid}

Cinnamic acid $(0.20 \mathrm{~mol})$ and dry benzene $(160 \mathrm{~mL})$ were placed in a round bottom flask. Anhydrous aluminum chloride ( $40 \mathrm{~g}$ ) was added slowly to the above solution and mixture was refluxed for $5 \mathrm{~h}$. The excess of benzene was removed by steam distillation. The solid so obtained was collected by filtration, washed with water and recrystallized from absolute ethanol.

\section{Synthesis of 3,3-diphenyl propanamide derivatives}

3,3-diphenyl propionic acid ( $0.01 \mathrm{~mol})$ was refluxed with $5 \mathrm{~mL}$ thionyl chloride for $1 \mathrm{~h}$. Excess of thionyl chloride was removed by distillation, and $15 \mathrm{~mL}$ of diethyl ether was added to round bottom flask containing 3,3-diphenyl propanoyl chloride and cooled over an ice bath. Substituted amine/amino acid $(0.01 \mathrm{~mol} / 0.02 \mathrm{~mol})$ was dissolved in diethyl ether and cooled over an ice bath. Ethereal solution of 3,3-diphenyl propanoyl chloride was added dropwise to previously mentioned solution of substituted amine/amino acid. After the completion of this process, the substituted amide derivatives (I-VIII) were precipitated, respectively, collected by filtration than treated with dil. $\mathrm{HCl}$ washed with water and recrystallized from absolute ethanol. The list of synthesized compounds including their physicochemical properties is presented in Table 1, 
reaction scheme is depicted in Scheme 1, and spectral characteristics of the synthesized derivatives are listed in Table 2.

\section{Biological screening}

Anthelmintic activity

\section{Collection of Stomoxys calcitrans and earthworms}

Houseflies (S. calcitrans) were trapped in a perforated sterile jar from recycling and waste disposable house of Moradabad Educational Trust Group of Institutions, Faculty of Pharmacy, Moradabad, Uttar Pradesh, India, and authentication was accomplished by Mr. Ramesh Kumar Gupta (Asst. Professor, Department of Pharmacology). The earthworms were collected from the soil of riverside at Ram Ganga Vihar, Moradabad, Uttar Pradesh, India.

\section{Housefly worm medium preparation}

The medium was prepared by adding (1.2 g) of beef extract powder in nutrient agar medium and $\mathrm{pH}$ was adjusted to 7.2 and sterilized in an autoclave (GPC Medical Ltd., Model AU201) at $121^{\circ} \mathrm{C}$ for $15 \mathrm{~min}$. Amoxicillin $(100 \mu \mathrm{g} / \mathrm{mL})$ and clotrimazole $(75 \mu \mathrm{g} / \mathrm{mL})$ were added to the medium to prevent the growth of microbes. $20 \mathrm{~mL} /$ Petri dish of sterilized media were transferred to 60 Petri dishes and secured for solidification. Five matured female houseflies were placed inside the Petri dishes which were closed immediately and kept at room temperature. After $24 \mathrm{~h}$, white colors eggs were hatched out by flies and died flies were removed. The Petri dishes were further cultured for the next $72 \mathrm{~h}$ evolving for the appearance of house fly worms. On generation of housefly worms, 20 worms from each dish were collected and weighed precisely in analytical balance to calculate the average weight of worm that was found to be $0.012 \mathrm{mg}$.

\section{Preparation of drug solutions}

Standard drug and compounds (I-VIII) were evaluated for anthelmintic potential at a concentration of $50 \mathrm{mg} / \mathrm{mL}$ and $100 \mathrm{mg} / \mathrm{mL}$ using $0.5 \%$ aq. solution of Tween 80 as a solvent.

\section{Arraying of housefly worms}

The cultured Petri dishes containing twenty S. calcitrans worms each were selected for anthelmintic activity [13], and dishes were categorized into different groups as follows. Group-A: Marked as (ABZ) for albendazole, consisting of 4 Petri dishes having $50 \mathrm{mg} / \mathrm{mL}$, and other 4 different Petri dishes having $100 \mathrm{mg} / \mathrm{mL}$ concentrations of albendazole. Group-(B-I): Marked as I, II, III, IV, V, VI, VII, and VIII, respectively, consisting of 4 Petri dishes/concentrations of synthesized compounds similar to the concentrations of albendazole. Group-J:

Table 1: List of synthesized compounds including their physicochemical properties

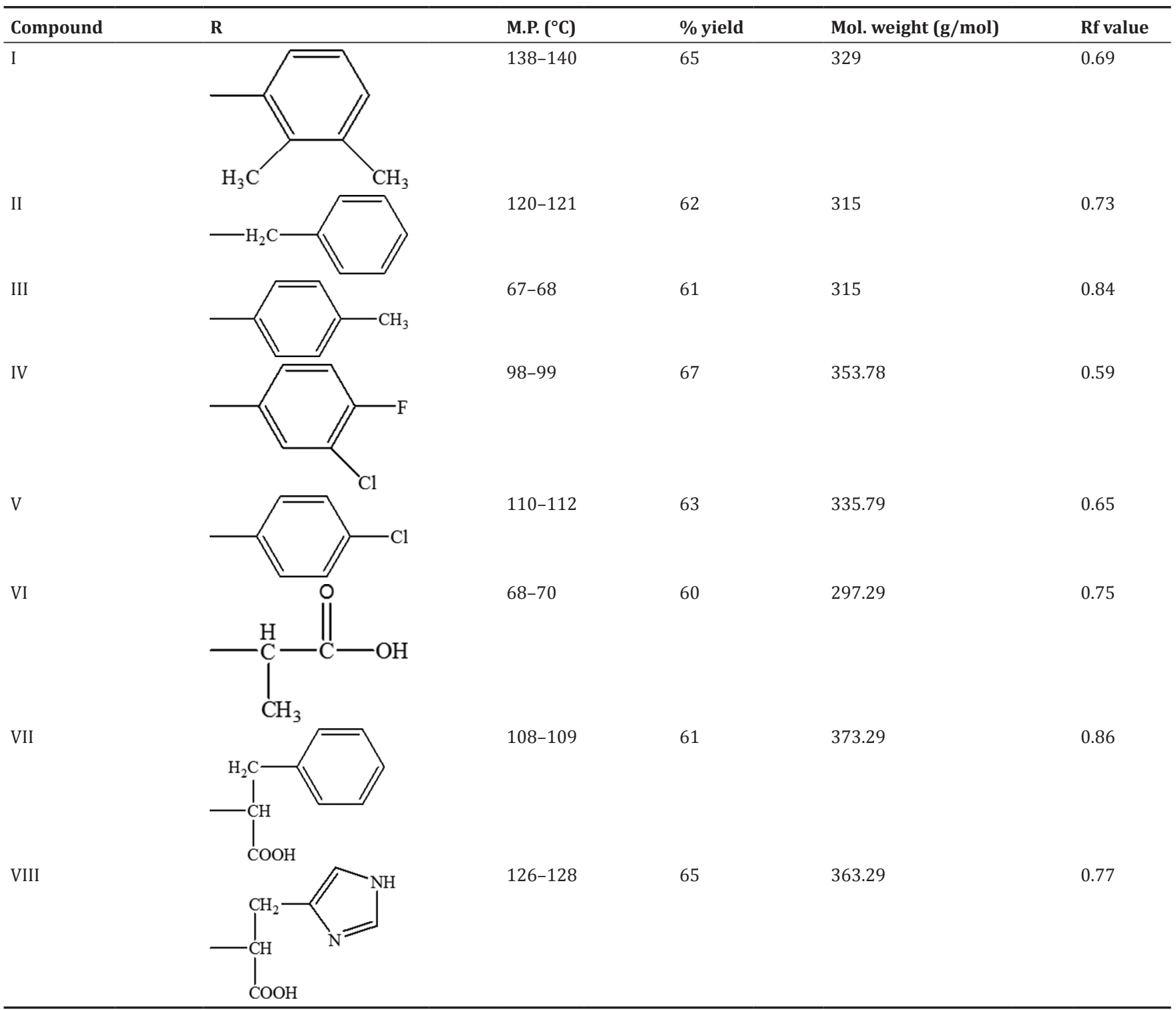




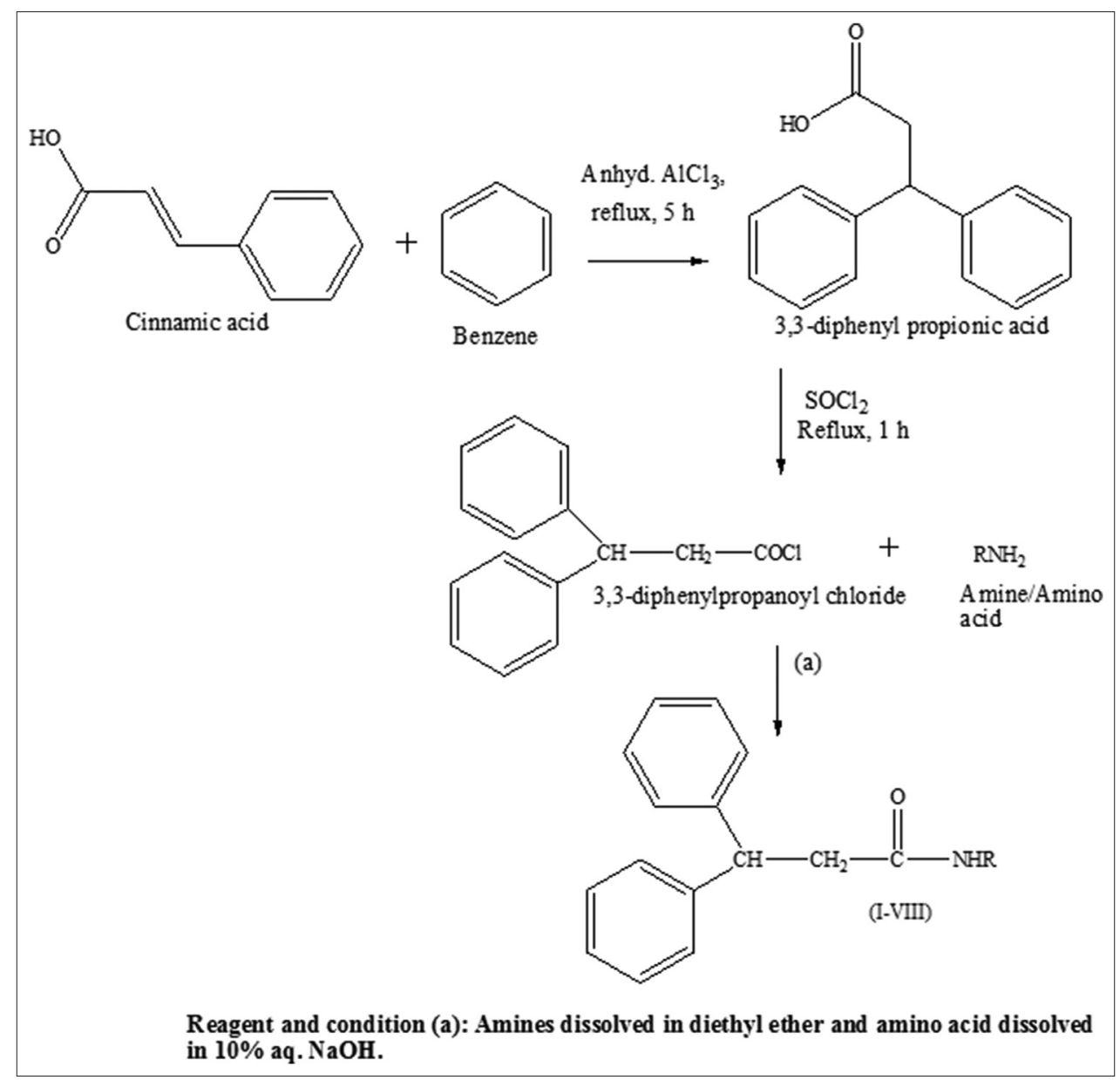

Scheme 1: Synthesis of 3,3-diphenyl propanamide derivatives. Reagent and condition (a) amines dissolved in diethyl ether and amino acid dissolved in $10 \%$ aq. $\mathrm{NaOH}$

Marked as a control having $0.5 \%$ aq. solution of Tween 80 , used in the same concentration as mentioned in the above two groups.

\section{Estimation of anthelmintic activity with housefly worms}

In each of the 8 Petri dishes/group, well having $1 \mathrm{~cm}$ diameter was bored with a borer at the center and for Group-A, $50 \mathrm{mg} / \mathrm{mL}$ of albendazole solution was poured in the well of first four Petri dishes of this group followed by adding $100 \mathrm{mg} / \mathrm{mL}$ of the same in last four Petri dishes of this group. The same technique was followed for pouring the solution of synthesized compounds (I-VIII) in their respective Groups-(B-I) along with Group-J, marked as a control. All the Petri dishes were incubated at $37^{\circ} \mathrm{C}$. The worms were evaluated for motility. This was done after tapping the edges of Petri dishes and allowing the worms to move freely toward the well, the worms that were alive would be seen moving. After paralysis, the worms were not able to show any motion which can be observed clearly by eyes. The unparalyzed worms were trapped toward the well, and incubation process was carried out again. Group-J, Petri dishes worms were viable for approximately 15 days with no sign of paralysis and death. The results are enlisted in Table 3.

\section{Estimation of anthelmintic activity using earthworm species}

Anthelmintic activity studies for synthesized derivatives were carried out against three different species of earthworms, Megascolex konkanensis, (ICARBC 211), Pontoscotex corethruses (ICARBC 117), and Eudrilus eugeniea (ICARBC 042) following Garg and Atal method [14-17] at concentration of $50 \mathrm{mg} / \mathrm{mL}$ and $100 \mathrm{mg} / \mathrm{mL}$, respectively, using $0.5 \%$ aq. solution of Tween 80. Three sets of Petri dishes with 4-inch diameter containing five earthworms of almost similar sizes/species (2 inches in length) in each set were prepared followed by categorization into three groups. Group-A: Marked as (ABZ) for albendazole having three sets (with respect to two different concentrations) each of three Petri dishes with three different earthworm species. Group-(B-I): Marked as I, II, III, IV, V, VI, VII, and VIII, respectively, having three sets (with respect to two different concentrations) each of the Petri dishes with five different earthworm species and Group-K: Marked as (C) for control having three sets (with respect to two different concentrations) each of three Petri dishes with five different earthworm species. The paralyzing and death time were noted, and their mean was calculated for each set. The death time was ascertained by placing the earthworms in warm water $\left(50^{\circ} \mathrm{C}\right)$ which stimulated the movement if the worm was alive. The results are presented in Table 4.

\section{Antibacterial and antifungal studies}

The synthesized compounds (I-VIII) were screened for their antimicrobial activity by cup-plate diffusion method using the MHA medium [18-20]. The microorganisms selected for antibacterial activity were Bacillus subtilis (NCIM 2063), Staphylococcus aureus (NCIM 2079), Pseudomonas aeruginosa (NCIM 2034), and Escherichia coli (NCIM 2065) and fungal strains Candida albicans (MUCC 29), Aspergillus niger (MUCC 29), Microsporum audouinii (MUCC 545), and Trichophyton mentagrophytes (MUCC 665) were selected for antifungal activity. The synthesized compounds were tested at a concentration of $50 \mu \mathrm{g} / \mathrm{mL}$. Ciprofloxacin for antibacterial activity and griseofulvin for antifungal activity were used as standard drugs at a concentration of $50 \mu \mathrm{g} / \mathrm{mL}$. The results of antibacterial and antifungal studies were presented in Tables 5 and 6, respectively.

\section{RESULTS AND DISCUSSION}

The described research work comprises the synthesis of novel 3,3-diphenyl propanamide derivatives. All the structures of novel synthesized derivatives were confirmed by IR and ${ }^{1} \mathrm{H}$-NMR spectral 
analysis. Structure of derivatives (I-VIII) was confirmed by the appearance of bands at $3300-3350 \mathrm{~cm}^{-1}$ (-NH str., amide) and $1690-1640 \mathrm{~cm}^{-1}$ ( $\mathrm{C}=0$ str., amide) and presence of aromatic rings in structures of compounds was confirmed by strong out-of-plane deformation bands ( $\mathrm{C}-\mathrm{H}$ bending) at $886-820 \mathrm{~cm}^{-1}$. Moreover, the structures of compounds were also confirmed by the appearance of

Table 2: Spectral characteristics of synthesized compounds

\begin{tabular}{|c|c|}
\hline Compound & IR $\left(\mathrm{KBr}, \mathrm{v}, \mathrm{cm}^{-1}\right),{ }^{1} \mathrm{H}-\mathrm{NMR}\left(300 \mathrm{MHz}, \mathrm{CDCl}_{3^{\prime}}, \delta, \mathrm{ppm}\right)$ \\
\hline I & $\begin{array}{l}3500-3350 \text { (N-H str.), 1600-1450 (C=C, str.), 900- } \\
700 \text { (C-H def.), } 1690 \text { (C=O), 1280-1278 (C-N str.) } \\
710-690 \text { (C-H, def.). 6.8-7.2 (m, 3H, Ar-H), 7.31 } \\
(\mathrm{s}, 1 \mathrm{H}, \mathrm{NH}), 2.18 \text { (2H, CH2), } 2.41 \text { (s, 3H, CH3), } 4.68 \\
\delta(\mathrm{s}, 1 \mathrm{H}, \mathrm{CH}), 2.26 \text { (s, 3H, CH3), } 7.40 \text { (s, 1H, -CONH) }\end{array}$ \\
\hline II & $\begin{array}{l}\text { 3040-3000 (C-H aromatic str.), 1600-1550 (C=C, } \\
\text { str.), } 900-720 \text { (C-H def.), } 1682 \text { (C=0), } 3325 \text { (NH str., } \\
\text { amide). 6.8-7.2 (m, } 15 \mathrm{H}, \mathrm{Ar}-\mathrm{H}), 7.31(\mathrm{~s}, 1 \mathrm{H}, \mathrm{NH}), \\
2.18(\mathrm{~s}, 2 \mathrm{H}, \mathrm{CH} 2), 4.68(\mathrm{~s}, 1 \mathrm{H}, \mathrm{CH}), 4.46(\mathrm{~s}, 2 \mathrm{H}, \mathrm{CH} 2) \text {, } \\
7.20(\mathrm{~s}, 1 \mathrm{H},-\mathrm{CONH})\end{array}$ \\
\hline III & $\begin{array}{l}1690 \text { (C=O), } 1577-1495 \text { (C=C, str.), } \\
3450-3300 \text { (N-H str.), } 3000 \text { (C-H str.), } 2.35 \text { (s, 3H, } \\
\text { CH3), } 7.70 \text { (s, 1H, -CONH), 6.5-7.5 (m, 14H, Ar-H), } 7.25 \\
(\mathrm{~s}, 1 \mathrm{H}, \mathrm{NH}), 4.52(\mathrm{~s}, 2 \mathrm{H}, \mathrm{CH} 2)\end{array}$ \\
\hline IV & $\begin{array}{l}1639 \text { (C=O str., amide), } 1529 \text { (N-H bend. amide), } \\
880-750 \text { (C-H def.), } 1670(\mathrm{C}=0), 6.2-7.5(\mathrm{~m}, 13 \mathrm{H}, \\
\text { Ar-H), } 4.52(\mathrm{~s}, 1 \mathrm{H}, \mathrm{CH}), 4.56(\mathrm{~s}, 2 \mathrm{H}, \mathrm{CH} 2), 8.0(\mathrm{~s}, 1 \mathrm{H}, \\
\mathrm{NH}), 7.30(\mathrm{~s}, 1 \mathrm{H},-\mathrm{CONH})\end{array}$ \\
\hline V & $\begin{array}{l}3400-3350 \text { (N-H str.), } 880-750 \text { (C-H def.), } \\
1670(\mathrm{C}=0), 6.3-7.0(\mathrm{~m}, 14 \mathrm{H}, \mathrm{Ar}-\mathrm{H}), 7.8(\mathrm{~s}, 1 \mathrm{H}, \mathrm{NH}), \\
4.25(\mathrm{~s}, 1 \mathrm{H}, \mathrm{CH}), 4.42(\mathrm{~s}, 2 \mathrm{H}, \mathrm{CH} 2), 7.65 \\
(\mathrm{~s}, 1 \mathrm{H},-\mathrm{CONH})\end{array}$ \\
\hline VI & $\begin{array}{l}3500-3350 \text { (N-H str.), 3050-3000 (C-H aromatic } \\
\text { str.), } 1600-1450 \text { (C=C, str.), 900-700 (C-H def.) } \\
1690(\mathrm{C}=0), 3000-2500(\mathrm{OH}, \mathrm{str}), 7.9(\mathrm{~s}, 1 \mathrm{H}, \mathrm{NH}) \\
4.28(\mathrm{~s}, 1 \mathrm{H}, \mathrm{CH}), 4.35(\mathrm{~s}, 2 \mathrm{H}, \mathrm{CH} 2), 7.60 \\
(\mathrm{~s}, 1 \mathrm{H},-\mathrm{CONH}), 11.0(\mathrm{~s}, 1 \mathrm{H}, \mathrm{OH})\end{array}$ \\
\hline VII & $\begin{array}{l}1680(\mathrm{C}=0), 2995-2650 \text { (OH str.), 3500-3330 (N-H } \\
\text { str.), } 4.64(\mathrm{~s}, 1 \mathrm{H}, \mathrm{CH}), 10.75(\mathrm{~s}, 1 \mathrm{H}, \mathrm{OH}), 1.43 \\
(\mathrm{~s}, 3 \mathrm{H}, \mathrm{CH} 3), 7.40(\mathrm{~s}, 1 \mathrm{H},-\mathrm{CONH}), 2.80(\mathrm{~s}, 1 \mathrm{H}, \mathrm{CH}) \\
8.10(\mathrm{~s}, 1 \mathrm{H}, \mathrm{NH}), 6.5-7.0(\mathrm{~m}, 10 \mathrm{H}, \mathrm{Ar}-\mathrm{H})\end{array}$ \\
\hline VIII & $\begin{array}{l}1675 \text { (C=O str.), } 1280-1275 \text { (C-N str.), } \\
3000-2500(\mathrm{O}-\mathrm{H} \text { str.), } 1600-1455 \text { (C=C str.), } 11.0 \\
(\mathrm{s}, 1 \mathrm{H}, \mathrm{OH}), 7.50(\mathrm{~s}, 1 \mathrm{H},-\mathrm{CONH}), 8.10(\mathrm{~s}, 1 \mathrm{H}, \mathrm{NH}) \\
7.10-7.16(\mathrm{~m}, 10 \mathrm{H}, \mathrm{Ar}-\mathrm{H}), 4.25(\mathrm{~s}, 2 \mathrm{H}, \mathrm{CH} 2)\end{array}$ \\
\hline
\end{tabular}

broad singlet at 7.80-7.25 ppm (for imino proton of CO-NH moiety) in ${ }^{1} \mathrm{H}$-NMR. The anthelmintic activity of synthesized compounds was tested against housefly worms and earthworm species. The results of anthelmintic activity were calculated on the basis of the time of paralysis and time of death as tabulated in Table 3, revealed that synthesized compounds (VII and VIII) exhibited good anthelmintic activity against housefly worms in dose-dependent manner, giving the shortest time of paralysis and death at $100 \mathrm{mg} / \mathrm{mL}$. The standard drug, albendazole exhibited paralysis at $25.00 \pm 0.32 \mathrm{~min}$ and death at $36.10 \pm 0.14 \mathrm{~min}$ at a concentration of $50 \mathrm{mg} / \mathrm{mL}$ and $24.00 \pm 0.13 \mathrm{~min}, 35.00 \pm 0.11 \mathrm{~min}$ at $100 \mathrm{mg} / \mathrm{mL} \mathrm{min}$, respectively. The compound VII at a concentration of $50 \mathrm{mg} / \mathrm{ML}$ causes paralysis at $24.45 \pm 0.10 \mathrm{~min}$ and death at $35.40 \pm 0.70 \mathrm{~min}$ and $23.55 \pm 1.10 \mathrm{~min}, 34.32 \pm 0.24 \mathrm{~min}$ at $100 \mathrm{mg} / \mathrm{mL}$, respectively. The compound VIII at a dose of $50 \mathrm{mg} / \mathrm{mL}$ causes paralysis at $24.30 \pm 0.65 \mathrm{~min}$ and death at $33.00 \pm 0.10 \mathrm{~min}$ and $23.45 \pm 0.14 \mathrm{~min}$, $34.20 \pm 0.65 \mathrm{~min}$ at $100 \mathrm{mg} / \mathrm{mL}$, respectively. The results discovered that the compounds VII and VIII at both concentrations are more effective than albendazole due to minimized mean paralyzing and mean death time as compared to albendazole. The comparison of the results between these two derivatives disclosed that compound VIII is more potent than compound VII due to minimal mean paralysis and mean death time.

The results in Table 4 revealed the anthelmintic potential of synthesized compounds against earthworm species. The standard drug, albendazole in three earthworm species, namely M. konkanensis, P. corethruses, and E. eugeniea at dose of 50 and $100 \mathrm{mg} / \mathrm{mL}$ caused paralysis at $12.32 \pm 0.40$, $10.34 \pm 0.22,13.10 \pm 0.10,11.11 \pm 0.40,12.15 \pm 0.12$, and $10.54 \pm 0.10 \mathrm{~min}$ and death at $17.02 \pm 0.10,14.10 \pm 0.25,16.11 \pm 0.12,14.35 \pm 0.22$, $16.45 \pm 0.14$, and $14.10 \pm 0.20 \mathrm{~min}$, respectively. The compounds VII and VIII in the same three earthworm species at a dose of 50 and $100 \mathrm{mg} / \mathrm{mL}$ declined the time of paralysis and death compared to that of albendazole. Therefore, it can be concluded that compounds VII and VIII are more effective anthelmintic agents than albendazole.

All the synthesized compounds (I-VIII) at dose of $50 \mu \mathrm{g} / \mathrm{mL}$ were screened for their antibacterial and antifungal activity by the cup-plate diffusion method using ciprofloxacin and griseofulvin as a standard drug at the same dose of $50 \mu \mathrm{g} / \mathrm{mL}$. The results of antibacterial in Table 5 expressed that all the compounds exhibited moderate to good activity, against Gram-negative bacterial strains (E. coli and P. aeruginosa) and minimal potential against Gram-positive bacterial strains (B. subtilis and S. aureus). The compounds IV, VII, and VIII represented $4.5-13.6 \%$ higher activity against $E$. coli and $10-30 \%$ higher activity against $P$. aeruginosa in comparison to ciprofloxacin. Hence, it can be concluded that these derivatives exhibited maximum

Table 3: Anthelmintic activity of compounds against housefly worms

\begin{tabular}{llll}
\hline Group & Concentration $(\mathbf{m g} / \mathbf{m L})$ & ${\text { Mean paralyzing time }(\mathbf{m i n})^{\mathrm{a}}}$ & Mean death time (min) $^{\mathrm{a}}$ \\
\hline A (ABZ) & 50 & $25.00 \pm 0.32$ & $36.10 \pm 0.14$ \\
& 100 & $24.00 \pm 0.13$ & $35.00 \pm 0.11$ \\
B (I) & 50 & $26.21 \pm 0.15$ & $39.00 \pm 0.10$ \\
& 100 & $25.20 \pm 0.18$ & $37.12 \pm 0.25$ \\
C (II) & 50 & $27.30 \pm 0.22$ & $38.10 \pm 0.20$ \\
& 100 & $26.28 \pm 1.10$ & $37.35 \pm 1.11$ \\
D (III) & 50 & $28.15 \pm 0.20$ & $37.26 \pm 0.20$ \\
& 100 & $27.10 \pm 0.10$ & $39.15 \pm 0.17$ \\
E (IV) & 50 & $26.25 \pm 1.25$ & $36.10 \pm 1.15$ \\
& 100 & $25.25 \pm 0.15$ & $38.45 \pm 0.25$ \\
F (V) & 50 & $27.40 \pm 0.10$ & $37.10 \pm 0.15$ \\
& 100 & $26.50 \pm 0.15$ & $37.09 \pm 0.13$ \\
G (VI) & 50 & $28.11 \pm 0.17$ & $35.28 \pm 0.22$ \\
& 100 & $25.38 \pm 0.16$ & $35.40 \pm 0.70$ \\
H (VII) & 50 & $24.45 \pm 0.10$ & $34.32 \pm 0.24$ \\
I (VIII) & 100 & $23.55 \pm 1.10$ & $33.00 \pm 0.10$ \\
J (C) & 50 & $24.30 \pm 0.65$ & $34.20 \pm 0.65$ \\
& 100 & $23.45 \pm 0.14$ & - \\
\hline
\end{tabular}

a Data are given as mean \pm S.D 
activity against Gram-negative bacterial strains as compared to the standard drug. Table 6 expressed the results of antifungal activity of synthesized compounds and results revealed that all the compounds were more active against (C. albicans and A. niger) in comparison with M. audouinii and T. mentagrophytes and the compounds IV, VII, and VIII, exhibited 5-20\% higher activity than griseofulvin against C. albicans and $15.78-31.5 \%$ higher activity against $A$. niger in comparison with standard drug griseofulvin.

\section{CONCLUSION}

This research demonstrated the synthesis of substituted 3,3-diphenyl propanamide derivatives. Anthelmintic activity was evaluated using housefly worms method and earthworm species model. The results of anthelmintic studies indicated good level of activity. The derivatives bearing amino acid moiety in the structure exhibited maximum anthelmintic, antibacterial, and antifungal activity. However, one fluoro, chloro substituted derivative represented maximum antibacterial and

Table 4: Anthelmintic activity of compounds against earthworm species

\begin{tabular}{|c|c|c|c|c|c|c|c|}
\hline \multirow[t]{2}{*}{ Group } & \multirow[t]{2}{*}{ Concentration $(\mathrm{mg} / \mathrm{mL})$} & \multicolumn{2}{|c|}{ Megascolex konkanensis } & \multicolumn{2}{|c|}{ Pontoscotex corethruses } & \multicolumn{2}{|c|}{ Eudrilus eugeniae } \\
\hline & & $\operatorname{MPT}(\min )^{a}$ & $\operatorname{MDT}(\min )^{a}$ & MPT (min) ${ }^{a}$ & $\operatorname{MDT}(\min )^{a}$ & $\operatorname{MPT}(\min )^{a}$ & $\operatorname{MDT}(\min )^{a}$ \\
\hline $\mathrm{A}(\mathrm{ABZ})$ & 50 & $12.32 \pm 0.40$ & $17.02 \pm 0.10$ & $13.10 \pm 0.10$ & $16.11 \pm 0.12$ & $12.15 \pm 0.12$ & $16.45 \pm 0.14$ \\
\hline \multirow[t]{2}{*}{$\mathrm{B}(\mathrm{I})$} & 50 & $14.50 \pm 0.11$ & $19.50 \pm 0.20$ & $15.43 \pm 0.54$ & $18.55 \pm 0.66$ & $14.47 \pm 0.22$ & $18.40 \pm 0.30$ \\
\hline & 100 & $12.30 \pm 0.20$ & $16.35 \pm 0.43$ & $13.20 \pm 0.45$ & $16.54 \pm 0.11$ & $12.50 \pm 0.25$ & $16.54 \pm 0.10$ \\
\hline \multirow[t]{2}{*}{ C (II) } & 50 & $15.20 \pm 0.20$ & $19.40 \pm 0.10$ & $15.40 \pm 0.45$ & $19.10 \pm 0.50$ & $14.27 \pm 0.11$ & $18.55 \pm 0.20$ \\
\hline & 100 & $12.55 \pm 0.10$ & $16.55 \pm 0.35$ & $13.10 \pm 0.25$ & $17.24 \pm 0.20$ & $12.45 \pm 0.10$ & $17.05 \pm 0.15$ \\
\hline \multirow[t]{2}{*}{ D (III) } & 50 & $14.55 \pm 0.14$ & $19.30 \pm 0.22$ & $15.20 \pm 0.14$ & $18.10 \pm 0.14$ & $14.10 \pm 0.35$ & $18.10 \pm 0.35$ \\
\hline & 100 & $12.45 \pm 0.66$ & $16.20 \pm 0.20$ & $13.05 \pm 0.15$ & $16.20 \pm 0.20$ & $12.10 \pm 0.25$ & $16.45 \pm 0.36$ \\
\hline \multirow[t]{2}{*}{$\mathrm{E}(\mathrm{IV})$} & 50 & $12.55 \pm 0.21$ & $17.10 \pm 0.25$ & $13.25 \pm 0.10$ & $16.55 \pm 0.45$ & $12.45 \pm 0.25$ & $16.55 \pm 0.25$ \\
\hline & 100 & $10.28 \pm 0.26$ & $14.15 \pm 0.58$ & $11.35 \pm 0.47$ & $15.12 \pm 0.54$ & $11.05 \pm 0.54$ & $14.45 \pm 0.21$ \\
\hline \multirow[t]{2}{*}{$F(V)$} & 50 & $14.05 \pm 0.21$ & $19.05 \pm 0.15$ & $14.40 \pm 0.42$ & $17.40 \pm 0.44$ & $13.35 \pm 0.21$ & $17.25 \pm 0.65$ \\
\hline & 100 & $12.10 \pm 0.20$ & $15.45 \pm 0.12$ & $12.45 \pm 0.25$ & $15.50 \pm 0.10$ & $12.05 \pm 0.10$ & $15.24 \pm 0.16$ \\
\hline \multirow[t]{2}{*}{ G (VI) } & 50 & $12.40 \pm 0.14$ & $17.45 \pm 0.15$ & $13.35 \pm 0.10$ & $16.25 \pm 0.14$ & $12.45 \pm 0.13$ & $17.10 \pm 0.11$ \\
\hline & 100 & $10.55 \pm 0.10$ & $14.20 \pm 0.25$ & $11.25 \pm 0.10$ & $15.25 \pm 0.25$ & $11.10 \pm 0.45$ & $14.40 \pm 0.14$ \\
\hline H (VII) & 50 & $12.10 \pm 0.10$ & $16.55 \pm 0.24$ & $12.75 \pm 0.10$ & $16.10 \pm 0.15$ & $12.15 \pm 0.10$ & $16.40 \pm 0.20$ \\
\hline \multirow[t]{2}{*}{ I (VIII) } & 50 & $12.15 \pm 0.35$ & $16.50 \pm 0.25$ & $12.45 \pm 0.10$ & $15.18 \pm 0.20$ & $11.35 \pm 0.26$ & $16.00 \pm 0.25$ \\
\hline & 100 & $10.00 \pm 0.25$ & $13.35 \pm 0.42$ & $10.17 \pm 0.20$ & $13.35 \pm 0.10$ & $10.40 \pm 0.11$ & $13.00 \pm 0.25$ \\
\hline \multirow[t]{2}{*}{$\mathrm{K}(\mathrm{C})$} & 50 & - & - & - & - & - & - \\
\hline & 100 & - & - & - & - & - & - \\
\hline
\end{tabular}

${ }^{a}$ Data are given as mean \pm S.D., MPT: Mean paralyzing time, MDT: Mean death time

Table 5: Antibacterial activity of compounds

\begin{tabular}{|c|c|c|c|c|}
\hline \multirow[t]{3}{*}{ Compound } & \multicolumn{4}{|c|}{ Diameter of the zone of inhibition ( $\mathrm{mm}$ ) } \\
\hline & \multicolumn{4}{|l|}{ Bacterial strains } \\
\hline & Bacillus subtilis & Staphylococcus aureus & Pseudomonas aeruginosa & Escherichia coli \\
\hline I & 10 & 12 & 17 & 18 \\
\hline II & 12 & 11 & 16 & 20 \\
\hline III & 16 & 14 & 17 & 17 \\
\hline IV & 16 & 17 & 22 & 23 \\
\hline VI & 13 & 13 & 21 & 17 \\
\hline VII & 15 & 16 & 24 & 23 \\
\hline VIII & 16 & 17 & 26 & 25 \\
\hline Control & - & - & - & - \\
\hline Ciprofloxacin & 17 & 18 & 20 & 22 \\
\hline
\end{tabular}

Table 6: Antifungal activity of compounds

\begin{tabular}{|c|c|c|c|c|}
\hline \multirow[t]{3}{*}{ Compound } & \multicolumn{4}{|c|}{ Diameter of the zone of inhibition ( $\mathrm{mm}$ ) } \\
\hline & \multicolumn{4}{|l|}{ Fungal strains } \\
\hline & Candida albicans & Microsporum audouinii & Aspergillus niger & Trichophyton mentagrophytes \\
\hline I & 18 & 16 & 16 & 15 \\
\hline II & 17 & 14 & 15 & 17 \\
\hline III & 19 & 17 & 18 & 13 \\
\hline IV & 21 & 16 & 22 & 19 \\
\hline $\mathrm{V}$ & 20 & 13 & 17 & 16 \\
\hline VI & 18 & 15 & 18 & 18 \\
\hline VII & 22 & 17 & 24 & 20 \\
\hline VIII & 24 & 17 & 25 & 20 \\
\hline Control & - & - & - & - \\
\hline Griseofulvin & 20 & 18 & 19 & 21 \\
\hline
\end{tabular}


antifungal activity in comparison with a standard drug. The findings suggested that amino acids derivatives of 3,3-diphenyl propanamide have magnificent future scope for further design and discovery as effective anthelmintics and antimicrobial agents.

\section{AUTHOR'S CONTRIBUTION}

The research methodologies were designed by Sachin Chaudhary and synthesis of the derivatives was performed by Harish Chandra Verma, Mandeep Kumar Gupta, and Sachin Chaudhary. The biological screening was performed by Ramesh Kumar Gupta. Amit Kumar and Abdel-Nasser El-Shorbagi contributed in designing of the manuscript.

\section{CONFLICTS OF INTEREST}

The authors have no conflicts of interest during the research.

\section{REFERENCES}

1. Alptuzun V, Parlar S, Tasli H, Erciyas E. Synthesis and antimicrobial activity of some pyridinium salts. Molecules 2009;14:5203-15.

2. Giannakaki V, Miyakis S. Novel antimicrobial agents against multidrug-resistant gram-positive bacteria: An overview. Recent Pat Antiinfect Drug Discov 2012;7:182-8.

3. Yu D, Huiyuan G. Synthesis and antibacterial activity of linezolid analogues. Bioorg Med Chem Lett 2002;12:857-9.

4. Koca M, Servi S, Kirilmis C, Ahmedzade M, Kazaz C, Ozbek B, et al. Synthesis and antimicrobial activity of some novel derivatives of benzofuran: Part 1. Synthesis and antimicrobial activity of (benzofuran-2-yl)(3-phenyl-3-methylcyclobutyl) ketoxime derivatives. Eur J Med Chem 2005;40:1351-8.

5. Dogruer DS, Onkol T, Ozkan S, Ozgen S, Sahin MF. Synthesis and antimicrobial activity of some $3(2 \mathrm{H})$-pyridazinone and $1(2 \mathrm{H})$ phthalazinone derivatives. Turk J Chem 2008;32:469-79.

6. Desai NC, Dodiya A, Shihory N. Synthesis and antimicrobial activity of novel quinazolinone-thiazolidine-quinoline compounds. J Saudi Chem Soc 2013; 17:259-69.

7. Prakash CR, Raja S. Synthesis, characterization and in vitro antimicrobial activity of some novel 5 -substituted schiff and mannich base of isatin derivatives. J Saudi Chem Soc 2013;17:337-44.

8. Dhall H, Sikka P, Kumar A, Mishra AK. Recent advancements and biological activities of aryl propionic acid derivatives: A review. Orient J Chem 2016;32:1831-8.

9. Landoni MF, Soraci A. Pharmacology of chiral compounds: 2-arylpropionic acid derivative. Curr Drug Metab 2001;2:37-51.

10. Singh SA, Bhat SV. Antimicrobial potential of 3-hydroxy-2-methylene3-phenylpropionic acid derivatives. Acta Pharm 2011;61:447-55.

11. Yamamoto T, Matsuura K, Shintani S, Hara A, Miyabe Y, Sugiyama T, et al. Dual effects of anti-inflammatory 2-arylpropionic acid derivatives on a major isoform of human liver 3alpha-hydroxysteroid dehydrogenase. Biol Pharm Bull 1998;21:1148-53.

12. Chikkula KV, Raja S. Isoxazole-A potent pharmacophore. Int J Pharm Pharm Sci 2017;9:13-24.

13. Murugamani V, Raju L, Raj VB, Kataki MS, Sankar GG. The new method development for evaluation of anthelmintic activity by housefly worms and compared with convenient earth worm method. ISRN Pharmacol 2012;2012:1-6.

14. Garg LC, Atal CK. Anthelmentic activity of Myrsine africana. Indian J Pharm Sci 1963;59:240-5

15. Chaudhary S, Kumar S, Tarazi H. Peptide derivatives of 1,2-dihydro-3methyl-2-oxoquinoxaline-6-carboxylic acid: Synthesis and evaluation of antimicrobial, antifungal and antiviral potential. Pharm Chem J 2016;12:281-8.

16. Chaudhary S, Kumar R, Gupta RK. Synthesis and biological activity of peptide derivatives of 2-hydroxy-5-(6-iodo-2-methyl-4-oxoquinazolin3(4H)-yl) benzoic acid. Asian J Pharm Clin Res 2012;5:196-200.

17. Chaudhary S, Kumar S. Synthesis and biological activity of peptide derivatives of 1,2-dihydro-3-methyl-2-oxoquinoxaline-6-carboxylic acid. Pharm Chem 2015;7:210-20.

18. Bhinge SD, Chature V, Sonawane V. Synthesis of some novel 1,3,4-thiadiazole derivatives and biological screening for anti-microbial, antifungal and anthelmintic activity. Pharm Chem J 2015;49:367-72.

19. Bauer AW, Kirby WM, Sherris JC, Turck M. Antibiotic susceptibility testing by a standardized single disk method. Am J Clin Pathol 1966;45:493-6.

20. Manjunatha KS, Satyanarayan ND, Harishkumar S. Antimicrobial and in silico ADMET screening of novel (E)-N-(2- $(1 \mathrm{H}-$ indol-3-yl-amino $)$ vinyl)-3-(1-methyl-1H-indol-3-yl)-3-phenylpropanamide derivatives. Int J Pharm Pharm Sci 2016;8:251-6. 